\title{
Topic of the Review Manuscript-The Review of Empowering Leadership
}

\author{
Tanveer Ahmed, Chaojun Yang, Hongjuan Yang, Salman Mahmood \\ Faculty of Management \& Economics, Kunming University of Science \& Technology, Kunming, China \\ Email: tmsurahio82cs@hotmail.com,yangcj84@163.com, 939738277@qq.com, salmankmust@gmail.com
}

How to cite this paper: Ahmed, T., Yang, C. J., Yang, H. J., \& Mahmood, S. (2021). Topic of the Review Manuscript-The Review of Empowering Leadership. Open Journal of Leadership, 10, 129-147. https://doi.org/10.4236/ojl.2021.102009

Received: April 18, 2021

Accepted: June 8, 2021

Published: June 11, 2021

Copyright (อ 2021 by author(s) and Scientific Research Publishing Inc. This work is licensed under the Creative Commons Attribution International License (CC BY 4.0).

http://creativecommons.org/licenses/by/4.0/ (c) (i) Open Access

\begin{abstract}
In view of experimental literature of empowering leadership, current work proposes reevaluating the adequacy regarding empowering leadership from multiple lookouts. Right off the bat, the paper begins with the detail depiction of empowerment as indicated by the perspectives on various authors along with the process of empowerment together with five stages model and furthermore examines the numerous successful ideas of empowering leadership from different points of view based on legitimate and experiential looks into. According to the literature survey it recaps the constructs as well as dimensional parameters of empowering leadership. From that point onward, based on exact investigates; it breaks down the two principle viewpoints of empowering leadership alongside the discrepancies of empowering leadership from interrelated leadership constructs. It is also exploration about the feasibility of empowering leadership at individual and gathering level. Finally, in the end it brings up the confinements of momentum research and a few perspectives regarding upcoming study.
\end{abstract}

\section{Keywords}

Leadership, Empowerment, Empowering Leadership, Leadership Constructs, Effectiveness, Perspectives

\section{Introduction}

In current era of research, in the field of management sciences, the perception of leadership is conceived as the fundamental pillar. Preceding studies use systematic behavior in the middle twentieth century that can be accompanied again to leadership trait theory (Li, Y. \& Wei, F., 2010). A while later, more exploration lying on the theory of leadership sprung out, containing the idea of fourgraph theory, leadership system model theory, situational leadership, dual fea- 
ture concepts of transformational and transactional leadership.

According to comprehensive distinguishing proof that individual and organizational factors assume an earth-shattering job that by what method people answer towards leadership conducts (Cheong et al., 2019; Lorinkova \& Perry, 2017; Zhang \& Bartol, 2010). In current era of study, ventures are challenging reflective revolution and commercial distraught. These fluctuations bring equal and unified organization structure, adaptability, client direction, the enhancement of superiority and expertise. Also, the work nature has rehabilitated a great deal. The aforementioned grow into increasingly mind confusing and demands with further perception. "Knowledgeable member of staff" grow into the center of the quickly growing work labor.

The commencement of empowerment leadership seems as a higher classification of pioneer on the foundation of such revolution. In 1990s the origination of empowerment leadership was projected. According to (Manz, C.C. \& Sims, H.P., 1990) empowerment leadership was conceived as the concept of "super leadership". Pearce projected the concept of four factor theory after expanding the theory of leadership comprising on transformational, transactional, instrumental and empowerment leadership thru Exploring Factor Analysis (EFA) (Pearce, et al. 2003). Furthermore, he established the aforementioned suitability throughout confirmatory factor analysis (CFA) by means of the tertiary trial. Consequently, empowerment leadership possibly will be unapproachable by way of an autonomous form of leadership.

As specified by Zhang \& Bartol (2010), empowering leadership is "the way on the way to objectifying circumstances that authorize offering dimensions on the way to a worker by means of showing the implication of the operative's action, giving further prominent basic leadership self-rule, collaborating belief in the worker's capabilities, in addition emptying interruptions to performance". Empowerment leadership accentuated the technique of subordinates' self-impact fairly than side by side control.

\section{Empowerment, Five Stages Process of Empowerment and Empowering Leadership}

Empowerment: In the last decades, empowerment has been a trendy study area (Bass \& Riggio, 2006). Although different authors described the impression of empowerment as the demonstration of empowering other individuals, further describe this idea as the internal procedures of the employee being engaged (Menon, 2001). It has been also described as a motivational (Tuckey et al., 2012) and multifaceted methodology that is made out of various practices planned for sharing data, rewards, resources and authority with employees at lower levels (Fernandez \& Moldogaziev, 2015). It is an understanding in the literature that empowered employees are described by being in a mental state called psychological empowerment. This is delineated by means of an intrinsic motivation revealed in four sensitivities; competence, meaning, self-determination and effect 
(Thomas \& Velthouse, 1990). Spreitzer, Kizilos and Nason (1997) deal with that the suspicion of empowerment initiates as of participative management and employee association theories. According managerial perspective, employee empowerment is a relational arrangement that describes how managers share data, power and resources with the individuals who need it (Fernandez \& Moldogaziev, 2015).

Five stages process of empowerment: The obligation to empower dependents turn out to be dangerous as soon as dependents feel immobilized. For this reason, it is extremely essential to recognize conditions in the internal organizations that replace with knowledge of inability among dependents. As soon as these circumstances are recognized, empowerment tactics and diplomacies can be used to abolish them. Nonetheless, moving external circumstances is not at all times conceivable, and it may not be acceptable intended for dependents to become empowered without the strategies and diplomacies in a straight line bring individual efficiency evidence to them. Bandura and Gervone (1986) indorsed numerous fundamentals as of which people in straight line obtain information approximately their individual efficiency, and these fundamentals ought to be utilized in developing empowerment approaches. According to this approach, the development of empowerment can be observed in five stages that comprises on the psychological circumstances of empowering understanding, its antecedent circumstances, and its behavioral consequences.

The five prime stages are stated in Figure 1. The very preliminary stage be located the progression of circumstances inside the organization which is officially in control for tactics of incapacity amongst dependents. Stage 2 leads to the utilization of empowerment approaches by managers. Stage 3 comprises on the employment of these procedures intended not only at reducing a few outer circumstances liable for inability, however likewise (and more significant) at provided that subordinates with self-efficacy information. As an outcome of receiving such information, subordinates be aware of empowered in Stage 4, finally behavioral belongings of empowerment are perceived in Stage 5.

Empowering leadership: In the literature of management the concept of empowering leadership has been specified superior courtesy. Empowering leadership stays definitely acknowledged through current form of providing self-sufficiency towards executive staffs (Lawler et al., 2001; Chamberlin et al., 2018). According to the originated opinion of consultants that empowering leadership optimistically belongings the innovativeness of the workers by means of enhancing the feeling of individuality amongst workers (Chow, 2018). Empowering leadership needs workers in knowledge sharing besides seek the data (Bunderson \& Sutcliffe, 2003; Mathieu et al., 2017). In short means, empowering leadership means giving employees more self-rule (Bass \& Riggio, 2006). Empowering pioneers also urge individuals to take an interest in basic leadership (Tuckey et al., 2012), delegate duties (Bass \& Riggio, 2006) and urge colleagues to cooperate and independently without direct supervision (Tuckey et al., 2012). 


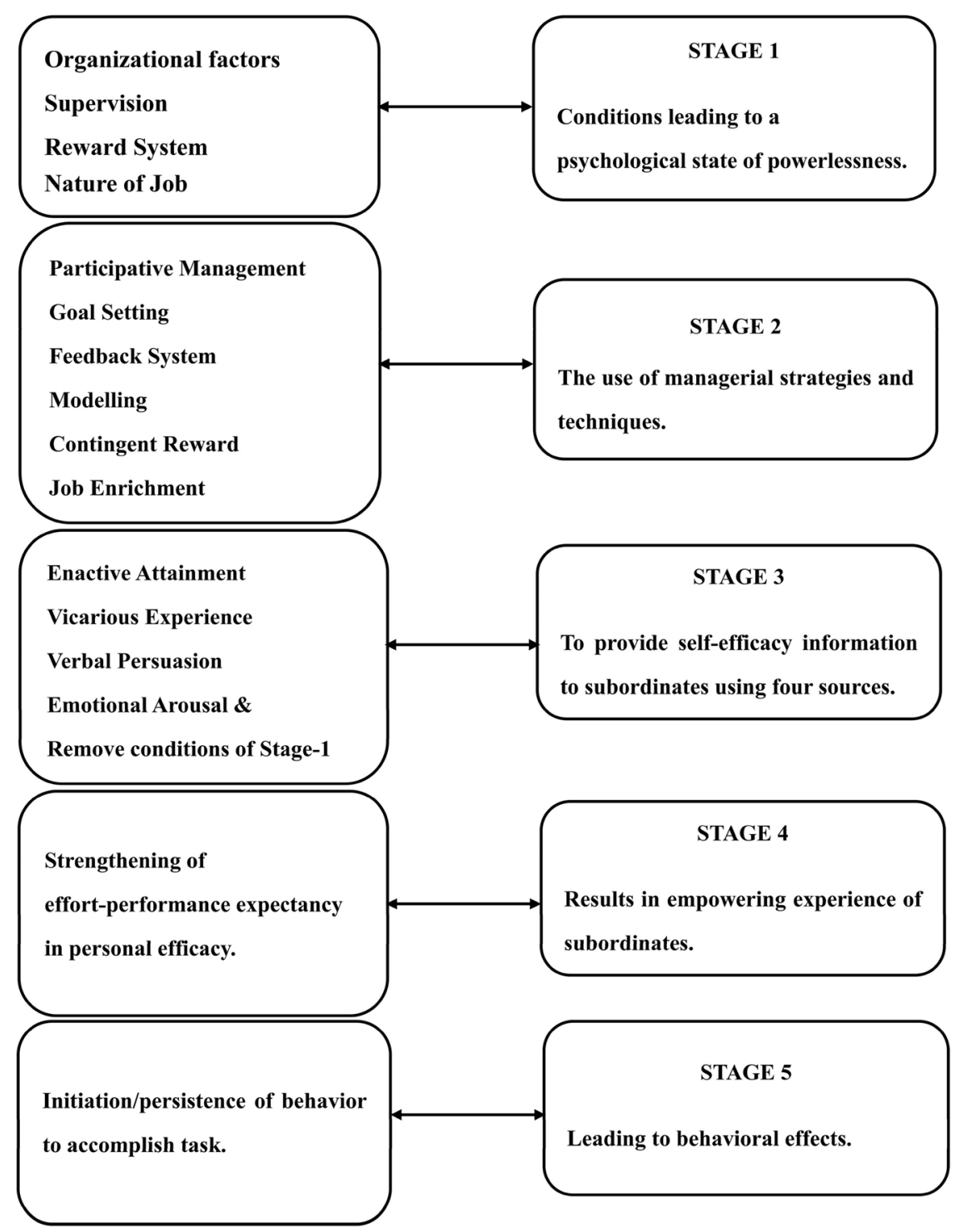

Figure 1. Five stages empowerment process.

Menon (2001) describes that effective empowering of devotees rely upon execution of organizational goals. Subsequently, empowerment of supporters can have negative results if the employees and the organization have various goals (Bass \& Riggio, 2006). Many scholars proven the notion of empowerment leadership as per the method of supremacy allocation, passing on self-sufficiency and dedication to followers, accumulations all the way thru explicit leader activities aimed at personnel on the way to intensify inner enthusiasm besides construct employment development (Ahearne, Mathieu, \& Rapp, 2005; Amundsen \& Martinsen, 2014a; Arnold, Arad, Rhoades, \& Drasgow, 2000; Sharma \& Kirkman, 2015; Sims Jr, Faraj, \& Yun, 2009; Strauss, 1964). Continuous expansion planned for the initiative regarding empowerment leadership has remained for the settlement thru excess of dependable leadership (Bowers \& Seashore, 1966); job trainings, employing methods stumped in conceptual theories con- 
taining situational leadership theory (Hersey, Blanchard, \& Natemeyer, 1979), participative leadership theory (Locke \& Schweiger, 1979), super leadership theory (Manz \& Sims Jr., 1990), and individualized leadership theory explaining regarding the sustainability of followers confidence (Dansereau et al., 1995). Bestowing to the view of Conger \& Kanungo (1988) and Thomas \& Velthouse (1990) worker empowerment is considered as "sharing of power" is not adequate and endorsed that employee empowerment have to integrate the motivational influence of empowerment on followers. Tuckey et al. (2012) initiated that empowering leadership could prompt increased psychological employment demands. They clarify this is an aftereffect of increased obligation and critical thinking given by the empowering pioneer to adherents. Furthermore, they originated that empowering pioneers increase employees' activity resources, and that the mix of increased resources and demands increased employees work commitment. Based in this, it is conceivable that empowering leadership prompts a procedure that may transform sentiments of worry to sentiments of vitality and enthusiasm for the work (Tuckey et al., 2012). Tuckey et al. (2012) contend that the reason for empowering leadership is to show employees self-leadership aptitudes. They contend this is done by allowing them the chance to adapt new things and help them to build up their capacities and abilities, as well as completing new duties. Therefore, empowering leadership is considered as a unique leadership style, which might be appropriate for the scholastic setting, taking into account how scholastics see leadership at their working environment.

\section{Two Main Perspectives of Empowering Leadership}

\subsection{Social Relationship Perspective}

Social relationship perspective focuses on the managerial viewers instigated on a collective affiliation or socio-structure lookout where a leader's empowering actions carry out momentous exertion (Arnold et al., 2000; Conger \& Kanungo, 1988; Manz \& Sims Jr., 1990; Strauss, 1964). For this motive, investigators perceived these ingenious actions of the leader, empowerment leadership levels, discriminate as of additional associated concepts of leadership. Five foremost proportions of empowering leadership notable via Arnold et al. (2000) containing "leading by example", "participative decision making", "coaching", "informing", and "demonstrating individual concern". According to (Ahearne et al., 2005) the scopes of empowering leadership encompassing on: "enhancing the meaningfulness of work", "fostering participation in decision making", "expressing confidence in high performance", and "providing autonomy from bureaucratic constraints". Amundsen and Martinsen (2015) deal with dual fundamental extents of empowering leadership are self-sufficiency and advancement support. According to social exchange theory, control is a commencement that can reproduce social concept. According to abovementioned articulated to the associated communal role together with the asymmetric or- 
ganize of resources along with end results within the background of a particular conditions and collective associations (Magee, J.C., et al., 2008). Dual features of strength recommend through mentioned clarification: it means observing others in addition to must be independent of others thus as to achieve objectives in organized manner. Supremacy always implements as a control tool. The one who have possession of authority be able to direct others to support them by means of achieving their objectives. According to further declaration, control is an ability not overstated by means of others. An individual always will be dependent lying on others underprivileged of authority and also will be reasonably free through control. Reason of the power is capable of the person's aptitude to deliver esteemed properties towards the organization. The abovementioned be proficient of his place in the organization structure, focused aptitudes along with possibility to entrance to vibrant facts and figures. Conferring toward mentioned viewpoint, empowerment mostly measured as resource allocation method that can be declined the requirement on top authority. Activities of the empowerment leadership could be classified by means of an evolution of administration performs, together with devolution, contribution, information allocation and guidance (Hakimi, N., et al., 2010, McClelland, D.C., 1975).

\subsection{Psychological Motivation Perspective}

Psychological motivation perspective, considered as an understanding along with motivational circumstances intricate meaning, proficiency, self-determination, and impact so as to replicates employees' psychosomatic reactions in the way of employees' assignation performs (Spreitzer, 1995; Thomas \& Velthouse, 1990). Empowerment leadership besides psychological empowerment, dual dissimilar commencements, enclosed within correspondingly hypothetical as well as investigational effort, leading to misperception besides collective consequences. In real meaning, empowering leadership is supposed to be a particular set of leader behavior that boost psychological empowerment, and for that reason expands many mandatory work fallouts (Maynard, Gilson, \& Mathieu, 2012; Seibert, Wang, \& Courtright, 2011; Zhang \& Bartol, 2010), concluding with the intention of empowering leadership probably will exertion as backdrop of psychological empowerment (e.g., "individual-level psychological empowerment": Amundsen \& Martinsen, 2015; "group level psychological empowerment": Lorinkova, Pearsall, \& Sims, 2013). Unequivocally, according to the psychological empowerment meta-analysis, Seibert et al. (2011) it is visibly recognized the study of psychological empowerment as of its associated idea of leadership, i.e., empowering leadership, via means of emphasizing: "More hurriedly blend of leadership and psychological empowerment thoughts give the impression to be a considerable growth justifying further study" (p. 998). Bestowing to Seibert et al. (2011), foremost executive performs, perception of leadership, socio-political sustainability along with the features of work strategy are situated in suitable backdrop of 
psychological empowerment. Conferring to psychological literature, supremacy besides control stay measured regarding designate the circumstances of persuasion person's inner motivation or expectation. Such as, an individual is well planned to have the need planned for control (McClelland, D.C., 1975). Power besides control have concerned devotion of numerous psychologists' devotion. Those researches join together control internally as well as externally, accomplishment, the key and secondary control. Employees influence requirements will be come across directly they observe with the intention of they have self-confidence inadequately grip life occurrences, state of relationships or individuals emotionally involved to them. Conversely, just the once the person senses with the aim of power is extremely low down, their ability necessities won't be meet. According to the perspective of this study, control is connected to an internal individuality defining claim in individual self-efficacy (Bandura, A. \& Gervone, D., 1986). Empowerment leadership behavior as of this perspective set collectively by any means managerial decisions or revolutions that can expand employees' inmost level of motivation by means of ornamental his autonomous command or self-productivity (Ahearne, J.M., et al., 2005; Conger, J.A. \& Kanungo, R.N., 1988). Giving the reflection of Thomas the idea of an empowerment is development planned for the level of intrinsic motivation, along with intended idea of "psychological empowerment" (Thomas, K.W. \& Velthouse, B.A., 1990). Spreitzer illustrated workers' study of attentiveness as the four distinctiveness of employees' awareness of work denotation, self-efficacy, self-government besides inspiration (Spreitzer, G.M., 1995).

\section{Difference of Empowering Leadership as of Interrelated Leadership Theories}

The thought of empowering leadership be originated lying on leader oriented recognized wisdoms, empowering leadership evaluation by means of further well-known leadership ideas are unavoidable. Even so, the aforementioned exclusive features of empowering leadership discriminate it as of further leadership theories be situated predetermined in leader support-related opinions, such as:

1) Path Goal;

2) Shared leadership;

3) Leader-Member Exchange (LMX);

4) Self-Leadership;

5) Ethical leadership;

6) Transformational Leadership;

7) Participative Leadership.

\section{1) Path Goal}

Path goal leadership theory considered as proposed background regarding associations among task oriented besides person-oriented administrator deeds as well enthusiasm besides fulfillment of supporters by means of features, in addition numerous front-line circumstances where such connotations will remain 
operative (House, 1971, 1996; House \& Mitchell, 1974). According to current strategy, House (1996) strengthened path goal theory on congregation level study though donated not any facts about this conception.

\section{Path Goal V/S. Empowerment Leadership}

Reformulated form of path goal theory (House, 1996) dialogs the opinion regarding supporter empowerment as well attain threats the conducts of achieving it over numerous groups of leader actions, for example, path goal instructive actions and success focused on leader actions (House, 1996; House \& Mitchell, 1974). A momentous idea of path goal theory, be that as it may, is an exciting and dictate loaded reflection taking place leader actions which possibly will offer supporters regarding required rigorous illuminations to assurance their work and associated activities would synthesis with the accomplishment of work impartial line and reaching appropriate rewards (House, 1996). Beside these appearances, this meta theory that highpoints several types of leader behaviors, obvious variations of supporters, in addition job circumstances along with to deal with leadership skill, is not the identical as the compassion of empowerment leadership that is considered as definite leader action proposing toward intensify supporters inner enthusiasm over power distribution besides giving supplementary self-sufficiency.

\section{2) Shared Leadership}

Shared leadership considered as joint technique on the way towards leadership which sights leadership through shared besides dissimilar assurance amongst followers (Yammarino, 2012). According to Pearce and Sims Jr. (2002) development regarding shared leadership via relating over vertical leadership, a conservative viewpoint on leadership which recommends leadership initiates as of decided leader of squad. The concept of shared leadership emphasis on leadership that increase beyond an environment besides team members or organizations, comparatively nominated recognized leader (Pearce \& Sims Jr., 2002).

\section{Shared V/S. Empowerment Leadership}

Even though historic idea regarding strength sharing thru expected leader remains segment containing dual ideas, on the opposing towards shared leadership, empowering leadership considered as explicit leader actions intended for authority distribution also passing on supplementary self-sufficiency besides tasks to supporters in organizations. Ultimate variance amongst shared \& empowering leadership that remain originated within the application of Pearce \& Sims Jr. (2002) and Ensley, Hmieleski, \& Pearce (2006). According to their study, shared leadership be supposed by means of nearby numerous categories of leader actions along with corresponding element, vertical leadership. Categorically, according twofold studies conceived thought of vertical empowerment besides shared empowerment leadership, at that time experimentally tried according to their potential (Pearce \& Sims Jr., 2002; Ensley et al., 2006). Furthermore, insofar as a degree of analysis view, concept of shared leadership remains twisted besides learned on cumulative degree of investigation then measured as happening 
on regularly dual levels (Carson, Tesluk, \& Marrone, 2007; Pearce \& Sims Jr., 2002; Yammarino, 2012).

\section{3) Leader-Member Exchange (LMX)}

LMX is well-defined authority of leader-member association (Gooty \& Yammarino, 2016; Graen \& Scandura, 1987; Graen \& Uhl-Bien, 1995; Liden, Erdogan, Wayne, \& Sparrowe, 2006). Conferring to the role theory besides social exchange theory, LMX cores about well-known associations amongst leaders besides members inside congregation as well entire supremacy of individuals relations (Dansereau, Graen, \& Haga, 1975; Graen \& Scandura, 1987; Graen \& Uhlbien, 1995) reaching from very low or no superiority to tremendously high aptitude.

\section{LMX V/S. Empowering Leadership}

Nonetheless numerous tentative studies recognized with top connotations among LMX besides empowering leadership (e.g., Amundsen \& Martinsen, 2014a; Hassan et al., 2013), particular descriptions of twin observation, empowerment leadership besides LMX remain theoretically rigorous. Empowerment leadership measured as productive leader actions relating to passing on responsibility as well authority, also enhancing individual motivation on the way to their everyday jobs. Prior studies pragmatically supporting difference among LMX besides empowerment leadership (see Amundsen \& Martinsen, 2014a; Tekleab et al., 2008).

\section{4) Self-Leadership}

Self-leadership described as set of methods that an individual carries out to establish as well encourage his/her specific actions, on behalf of that individual's investigation confined by themselves to achieve the explanations of motivation and control of their inner state of affairs and proceedings (Manz \& Sims Jr., 1980).

\section{Self-Leadership V/S Empowering Leadership}

While the identical perceptions regarding self-leadership besides empowerment leadership used as one of the worker empowerments concludes that permit leaders to be reallocated in more foremost managerial actions (Markham \& Markham, 1995), empowering leadership impression stays obviously outstanding in relation towards self-leadership. Empowering leadership considered as leader actions assessed towards growth of supporters' seeming reputation besides inevitability nearby work, involvement, besides freedom of autonomy. According to discrepancy, self-leadership considered as different critical activities that employees put on over them to control their individual performances. Like this, empowerment leader actions possibly will act as indirect distressing supporters' self-leadership. By means of continuing realities, (Yun et al. 2006) initiated leader's empowerment actions absolutely exaggerated supporters' selfleadership relating over supporters' obligation for self-sufficiency.

\section{5) Ethical Leadership}

Ethical leadership principally cores universally leaders' direction concerning to making perfect decision, being autonomous, distribution of goodness, also 
leading others within exact tactic through working together concerning ethics, ethical methods, as well satisfying dependents' moral deeds. Intrinsically, leaders containing ethical norms transmute supporters' legal responsibility regarding ethical actions (Brown \& Treviño, 2006; Den Hartog, 2015; Dionne et al., 2014; Hassan, Mahsud, Yukl, \& Prussia, 2013; Palanski \& Yammarino, 2009).

\section{Ethical V/S. Empowering Leadership}

While the aforesaid possibly will be crucial strategy intended for empowerment leaders grounded towards proper direction, empowerment leadership isn't moderately equivalent incidentally for the idea of ethical leadership for the motive that an empowering leader's direction isn't considerate right perception. Let's say, ethical leaders possibly will burden moral values besides directions among several job actions, nevertheless possibly will at present-day grasp the majority of decision making throughout not assigning those to their followers.

\section{6) Transformational Leadership}

Previously transformational leadership considered as principal model of leadership (Day \& Antonakis, 2012), afterward denotes to leader actions ended out on four levels: idealized collision, inspirational motivation, individualized consideration and intellectual stimulation. Paying consideration that motivates supporters for assigning and asking about conception together with encouraging them for job to endorse the organization (Bass, 2008; Bass \& Steidlmeier, 1999; Yammarino \& Bass, 1990; Yukl, 2002).

\section{Transformational Leadership V/S. Empowerment Leadership}

However uninterrupted experimental studies mentioned high relations amongst transformational leadership besides empowerment leadership (e.g., Amundsen \& Martinsen, 2014a), in difference towards transformational leaders, empowerment leaders necessitate inside the actions that will in total growth to each follower's real individual capability amongst group associates (Manz \& Sims Jr., 1987, 2001). Further, it might remain well planned reputation taking place stay yourself practically than be ourselves. In accord through this development, numerous studies contribute experimentally sustained the dissimilarity amongst transformational leadership and empowerment leadership (e.g., Amundsen \& Martinsen, 2014a; Arnold et al., 2000; Pearce \& Sims Jr., 2002). Likewise, through pure sub-dimensions distinction which build concepts beyond transformational leadership besides empowerment leadership, prime part of empowerment leadership informs towards giving self-sufficiency to supporters, in addition thru supporters for the purpose of decision making. Such proportions remain improper within the extents that form transformational leadership (Ahearne et al., 2005; Arnold et al., 2000).

\section{7) Participative Leadership}

Participative leadership specifies in the direction of leader behaviors that involve supporters into communal decision making and also giving an authority in the process of decision making by means of supporters (Armenakis, Harris, \& Mossholder, 1993; Lam, Huang, \& Chan, 2015). Participative leadership formed normative model origination relating to decision making executed by the leader 
(Vroom \& Yetton, 1973; Vroom \& Jago, 2007). Forefront mainstream motivation at the back-hand succession of the normative decision-making model to identify leader's dual wide-ranging decision-making styles, participative \& autocratic, besides all reliable decisions of decision-making styles within numerous conditions stranded on 11 decision investigative (Vroom \& Yetten, 1973).

\section{Participative V/S. Empowering Leadership}

Even though the dual views participative besides empowering leadership declare self-motivated existence of followers throughout the evolution of decisionmaking, empowering leadership also imitates an extensive thought and integrates the thought of supporters' participative level decision making by means of secondary component (Ahearne et al., 2005; Arnold et al., 2000). Further, participative leader actions remain decisive features, though not suitable situation meant for empowering leadership.

(Amundsen \& Martinsen, 2014a; Pearce \& Sims Jr., 2002; Tekleab, Sims Jr., Yun, Tesluk, \& Cox, 2008) sanctions empowerment leadership idea by means of exceptional besides self-directed idea (Sharma \& Kirkman, 2015). Matters linked toward concept expulsion in all activities of leadership rise by means of a wide-ranging serious anxiety (Banks, Gooty, Ross, Williams, \& Harrington, 2018; Meuser et al., 2016), in addition, theory cropping or fortifying the "theoretical space" of particular leadership idea of consideration is convincing.

The concepts offered in following Table 1: determine the theoretical emphasis amongst empowerment leadership besides associated theories of leadership.

\section{The Effectiveness of Empowering Leadership}

According synthesizing study, Raub discovered empowerment leadership at dissimilar level (Raub, S. \& Robert, C., 2010). The study discovered the expansion of collaborative outcome variables at several stages since the observation of empowerment leadership besides psychological empowerment practices. Study model stands in Figure 2, that combined obligation focused on in-job actions besides interactive relationship focused on exterior job behavior of understanding besides the motivating rank absorbed on stimulating exterior work deeds. The study recognized the probability containing empowerment leadership on worker's interactive consequences on tierce stages in addition recognized psychological empowerment as substantial central variable among the empowerment leadership besides stimulating external job action. Gao focused motivating exterior job conduct, voice conduct of workers as of telecommunication business besides exposed worker's trust among manager besides empowerment leadership conduct remained substantial features towards advance worker voice (Gao, L., Janssen, O., \& Shi, K., 2011). Chen reviewed the mechanism regarding the influence of empowerment leadership on team supporters, furthermore initiated that empowerment leadership definitely overstated association \& innovative conduct of team over psychological empowerment besides sentimental liability (Chen et al. 2011). 
Table 1. Theoretical emphasis amongst empowering leadership and associated leadership theories.

\begin{tabular}{rc}
\hline \multicolumn{1}{c}{ Type of Leadership } & Emphasis \\
\hline 1) Empowerment leadership & Behavioral style towards leadership \\
2) Path goal theory & Meta-theoretical framework \\
3) Shared leadership & Collectivistic style towards leadership \\
4) Leader-member exchange (LMX) & Relationship-based style towards leadership \\
5) Self-leadership & Principal person's behavioral style \\
6) Ethical leadership & Behavioral style towards leadership \\
7) Transformational leadership & Behavioral style towards leadership \\
8) Participative leadership & Behavioral style towards leadership
\end{tabular}

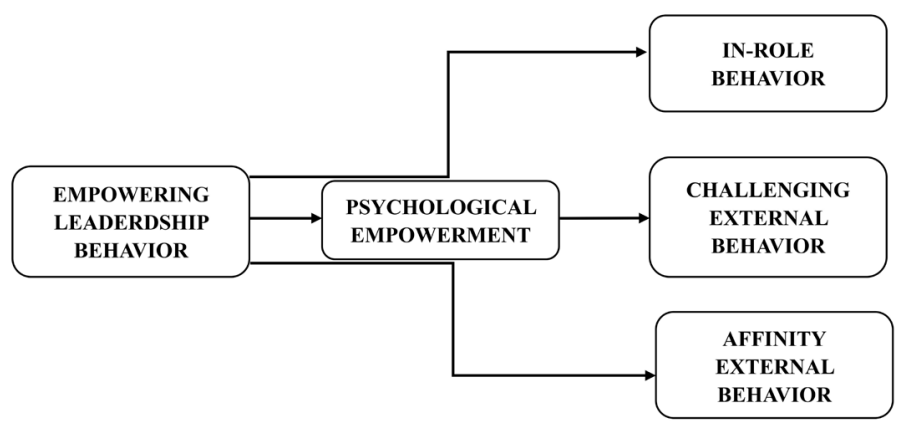

Figure 2. Empowerment leadership effectiveness model of (Raub, S. \& Robert, C., 2010).

Kirkman launched investigational study reagrding empowerment leadership through observation of congregation level in Figure 3 (Kirman, B.L. \& Rosen, B., 1999). Samples were chosen as of four corporations based on United States, two stayed large corporations besides two small corporations. Consequences stated regarding empowerment leadership based on gathering level contained four extents power, meaningfulness, autonomy and impact was further legally responsible on the way to enlarge organizational performance for making decisions by means of traditional leadership. According Humborstad, empowerment leadership remained significant towards work performance (Humborstad et al., 2014). Wellins initiated that the empowered team was moreover practical, perceiving for uninterrupted upgrading planned for the work superiority, continuous work growing improvement, explorating inventive results (Wellins et al., 1991). Guzzo restrained the team with innovative consciousness of the ability would give enhanced facility of equally internal and external customers (Guzzo, R.A., et al., 1991). Gorn measured worker's work contentment must be progressive once work was supplementary expressive (Gorn, G.J. \& Kanungo, R.N., 1980). Cordery initiated the empowered team had innovative organizational liability level associated thru the traditional team in the similar corporation (Cordery, J.L., Mueller, W.S., \& Smith, L.M., 1991). Kirkman supposed that the upcoming study ought to emphasis containing individual and group level combination (Kirman, B.L. \& Rosen, B., 1999). 


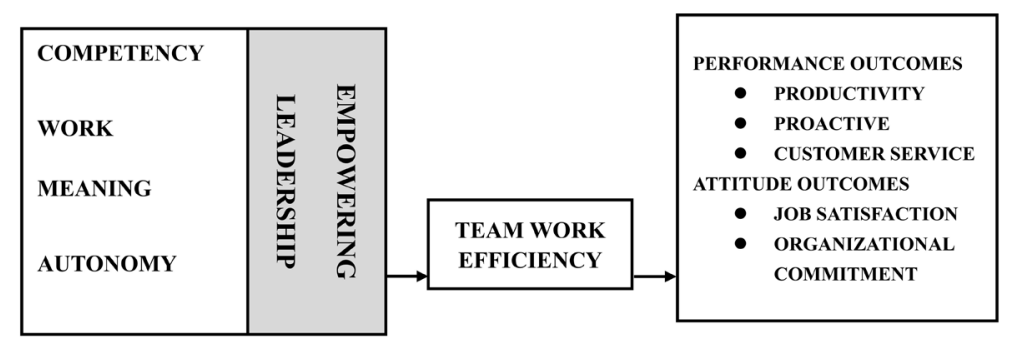

Figure 3. Empowerment leadership effectiveness model of (Kirman, B.L. \& Rosen, B., 1999).

\section{Conclusion and Future Work}

Conferring to the assessment of the investigational literature regarding empowerment leadership, the present work recommends reconsidering empowerment leadership assessment over background of several approaches. According to empowerment leadership, team besides employees has preferred together with additional self-sufficiency, self-leadership as well controlling of work conditions. Alternatively, it is essential for executives to offer sustenance, comforting selfmanagement as well growing empowerment. Recognized organization must be well regulated for proper business atmosphere alteration agreed over increasingly forceful international rivalry that encounter customer essentials planned regarding innovative belongings capability also describe alteration from industrial actions to support oriented ventures. Hence, executives must pay dedication towards empowerment leadership training activities alike offering sustenance besides inspiration, reorganizing participative decision-making, team leading along with assuming new job besides responsibility. While empowering leadership study receiving extra dedication from late, there are some difficulties and shortages in the present research. By means of a matter of first importance, the empowerment leadership theory initiates as of Western cultural background. Western scholars used up great contract containing studies regarding empowerment leadership structure as of substitute points of view; besides have finalized abundant activities by means of empowerment leadership scales for numerous formed situations. The current study typically admits the individual measurement survey process that is easy for errors transfer. Empowerment leadership has measured as of substitute points of view by joining over complex methods as case study besides inside and out meeting to guarantee the exactness.

Likewise, future research would to assign extra weightage regarding investigational acceptability of empowerment leadership measure. Correspondingly, throughout prior studies, it is evidently exposed that study comprising empowerment leadership outcome variables centers about individual \& gathering level. Hence, anticipate in the direction of reduced courtesy meant for empowerment leadership stimulation on shareholders inside industrial chain at organizational level. Western culture designed the item economy that considered through strong freedom besides inappropriate control variation. The future study will emphasis regarding empowerment leadership distinction according several social circums- 
tances as of cross culture lookout. In conclusion, I wanted to recap current empowerment leadership literature also propose dual innovative lines of demand to implicitly expand prior work. Certainly, majority of empowerment leadership studies have focused on constructive results, I recommend that forthcoming work must study features that are possibly going to 1) forecast empowerment leadership and 2) describe the procedures over which more negative besides unintentional, negative influences of empowerment leadership are possibly going to happen.

\section{Conflicts of Interest}

The authors declare no conflicts of interest regarding the publication of this paper.

\section{References}

Ahearne, J.M., Mathieu, J., \& Rapp, A. (2005). To Empower or Not to Empower Your Sales Force? An Empirical Examination of Influence of Leadership Empowerment Behavior on Customer Satisfaction and Performance. Journal of Applied Psychology, 90, 945-955. https://doi.apa.org/doi/10.1037/0021-9010.90.5.945

Amundsen, S., \& Martinsen, Ø. L. (2014a). Empowering Leadership: Construct Clarification, Conceptualization, and Validation of a New Scale. The Leadership Quarterly, 25, 487-511. https://doi.org/10.1016/j.leaqua.2013.11.009

Amundsen, S., \& Martinsen, Ø. L. (2015). Linking Empowering Leadership to Job Satisfaction, Work Effort, and Creativity: The Role of Self-Leadership and Psychological Empowerment. Journal of Leadership and Organizational Studies, 22, 304-323. https://doi.org/10.1177\%2F1548051814565819

Armenakis, A. A., Harris, S. G., \& Mossholder, K. W. (1993). Creating Readiness for Organizational Change. Human Relations, 46, 681-703. https://doi.org/10.1177\%2F001872679304600601

Arnold, J. A., Arad, S., Rhoades, J. A., \& Drasgow, F. (2000). The Empowering Leadership Questionnaire: The Construction and Validation of a New Scale for Measuring Leader Behaviors. Journal of Organizational Behavior, 21, 249-269.

Bandura, A., \& Gervone, D. (1986). Differential Engagement of Self-Reactive Influences in Cognitive Motivation. Organizational Behavior \& Human Decision Processes, 38, 92-113. https://doi.org/10.1016/0749-5978(86)90028-2

Banks, G. C., Gooty, J., Ross, R. L., Williams, C. E., \& Harrington, N. T. (2018). Construct Redundancy in Leader Behaviors: A Review and Agenda for the Future. The Leadership Quarterly, 29, 236-251. https://doi.org/10.1016/j.leaqua.2017.12.005

Bass, B. M. (2008). The Bass Handbook of Leadership: Theory, Research, and Managerial Applications (4th ed.). New York, NY: Free Press.

Bass, B. M., \& Riggio, R. E. (2006). Transformational Leadership. New York, NY: Psychology Press. https://doi.org/10.4324/9781410617095

Bass, B. M., \& Steidlmeier, P. (1999). Ethics, Character, and Authentic Transformational Leadership Behavior. The Leadership Quarterly, 10, 181-217. https://doi.org/10.1016/S1048-9843(99)00016-8

Bowers, D. G., \& Seashore, S. E. (1966). Predicting Organizational Effectiveness with a Four-Factor Theory of Leadership. Administrative Science Quarterly, 11, 238-263. https://doi.org/10.2307/2391247 
Brown, M. E., \& Treviño, L. K. (2006). Ethical Leadership: A Review and Future Directions. The Leadership Quarterly, 17, 595-616. https://doi.org/10.1016/j.leaqua.2006.10.004

Bunderson, J. S., \& Sutcliffe, K. M. (2003). Management Team Learning Orientation and Business Unit Performance. Journal of Applied Psychology, 88, 552-560. https://doi.apa.org/doi/10.1037/0021-9010.88.3.552

Carson, J. B., Tesluk, P. E., \& Marrone, J. A. (2007). Shared Leadership in Teams: An Investigation of Antecedent Conditions and Performance. Academy of Management Journal, 50, 1217-1234.

Chamberlin, M., Newton, D. W., \& LePine, J. A. (2018). A Meta-Analysis of Empowerment and Voice as Transmitters of High-Performance Managerial Practices to Job Performance. Journal of Organizational Behavior, 39, 1296-1313.

https://doi.org/10.1002/job.2295

Chen, G., Sharma, P. N., Edinger, S. K., Shapiro, D. L., \& Farh, J. L. (2011). Motivation and Demotivating Forces in Teams: Cross-Level Influence of Empowering Leadership and Relationship Conflict. Journal of Applied Psychology, 96, 541-557.

https://doi.apa.org/doi/10.1037/a0021886

Cheong, M., Yammarino, F. J., Dionne, S. D., Spain, S. M., \& Tsai, C. Y. (2019). A Review of the Effectiveness of Empowering Leadership. The Leadership Quarterly, 30, 34-58. https://doi.org/10.1016/j.leaqua.2018.08.005

Chow, I. H. S. (2018). The Mechanism Underlying the Empowering Leadership-Creativity Relationship. Leadership \& Organization Development Journal, 39, 202-217. https://doi.org/10.1108/LODJ-03-2016-0060

Conger, J. A., \& Kanungo, R. N. (1988). The Empowerment Process: Integrating Theory and Practice. Academy of Management Review, 13, 471-482. https://doi.org/10.5465/amr.1988.4306983

Cordery, J. L., Mueller, W. S., \& Smith, L. M. (1991). Attitudinal and Behavioral Effects of Autonomous Group Working: A Longitudinal Field Study. The Academy of Management Journal, 34, 464-476.

Dansereau, F., Graen, G., \& Haga, W. J. (1975). A Vertical Dyad Linkage Approach to Leadership within Formal Organizations: A Longitudinal Investigation of the Role Making Process. Organizational Behavior and Human Performance, 13, 46-78.

https://doi.org/10.1016/0030-5073(75)90005-7

Dansereau, F., Yammarino, F. J., Markham, S. E., Alutto, J. A., Newman, J., Dumas, M., \& Lee, S. (1995). Individualized Leadership: A New Multiple-Level Approach. The Leadership Quarterly, 6, 413-450. https://doi.org/10.1016/1048-9843(95)90016-0

Day, D. V., \& Antonakis, J. (Eds.). (2012). The Nature of Leadership (2nd ed.). Los Angeles, CA: Sage.

Den Hartog, D. N. (2015). Ethical Leadership. Annual Review of Organizational Psychology and Organizational Behavior, 2, 409-434. https://doi.org/10.1146/annurev-orgpsych-032414-111237

Dionne, S. D., Gupta, A., Sotak, K. L., Shirreffs, K. A., Serban, A., Hao, C., \& Yammarino, F. J. (2014). A 25-Year Perspective on Levels of Analysis in Leadership Research. The Leadership Quarterly, 25, 6-35. https://doi.org/10.1016/j.leaqua.2013.11.002

Ensley, M. D., Hmieleski, K. M., \& Pearce, C. L. (2006). The Importance of Vertical and Shared Leadership within New Venture Top Management Teams: Implications for the Performance of Startups. The Leadership Quarterly, 17, 217-231.

https://doi.org/10.1016/j.leaqua.2006.02.002 
Fernandez, S., \& Moldogaziev, T. (2015). Employee Empowerment and Job Satisfaction in the US Federal Bureaucracy: A Self-Determination Theory Perspective. The American Review of Public Administration, 45, 375-401. https://doi.org/10.1177\%2F0275074013507478

Gao, L., Janssen, O., \& Shi, K. (2011). Leader Trust and Employee Voice: The Moderating Role of Empowering Leader Behaviors. The Leadership Quarterly, 22, 787-798. https://doi.org/10.1016/j.leaqua.2011.05.015

Gooty, J., \& Yammarino, F. J. (2016). The Leader-Member Exchange Relationship: A Multisource, Cross-Level Investigation. Journal of Management, 42, 915-935. https://doi.org/10.1177\%2F0149206313503009

Gorn, G. J., \& Kanungo, R. N. (1980). Job Involvement and Motivation: Are Intrinsically Motivated Managers More Job Involved? Organizational Behavior and Human Performance, 26, 265-277. https://doi.org/10.1016/0030-5073(80)90059-8

Graen, G. B., \& Scandura, T. A. (1987). Toward a Psychology of Dyadic Organizing. Research in Organizational Behavior, 9, 175-208.

Graen, G. B., \& Uhl-Bien, M. (1995). Relationship-Based Approach to Leadership: Development of Leader-Member Exchange (LMX) Theory of Leadership over 25 Years: Applying a Multi-Level Multi-Domain Perspective. The Leadership Quarterly, 6, 219247. https://doi.org/10.1016/1048-9843(95)90036-5

Guzzo, R.A. et al. (1991). What Makes High-Performing Teams Effective? Unpublished Manuscript, College Park, MD: University of Maryland.

Hakimi, N., Van Knippenberg, D., \& Giessner, S. (2010). Leader Empowering Behavior: The Leader's Perspective. British Journal of Management, 21, 701-716. https://doi.org/10.1111/j.1467-8551.2010.00703.x

Hassan, S., Mahsud, R., Yukl, G., \& Prussia, G. E. (2013). Ethical and Empowering Leadership and Leader Effectiveness. Journal of Managerial Psychology, 28, 133-146. https://doi.org/10.1108/02683941311300252

Hersey, P., Blanchard, K. H., \& Natemeyer, W. E. (1979). Situational Leadership, Perception, and the Impact of Power. Group \& Organization Studies, 4, 418-428. https://doi.org/10.1177\%2F105960117900400404

House, R. J. (1971). A Path Goal Theory of Leader Effectiveness. Administrative Science Quarterly, 16, 321-339. https://doi.org/10.2307/2391905

House, R. J. (1996). Path-Goal Theory of Leadership: Lessons, Legacy, and a Reformulated Theory. The Leadership Quarterly, 7, 323-352. https://doi.org/10.1016/S1048-9843(96)90024-7

House, R. J., \& Mitchell, T. R. (1974). Path-Goal Theory of Leadership. Journal of Contemporary Business, 9, 81-97.

Humborstad, S. W., Nerstad, C. G. L., \& Dysvik, A. (2014). Empowering Leadership, Employee Goal Orientations and Work Performance: A Competing Hypothesis Approach. Personnel Review, 43, 246-271. https://doi.org/10.1108/PR-01-2012-0008

Kirman, B.L., \& Rosen, B. (1999). Beyond Self-Management: Antecedents and Consequences of Team Empowerment. Academy of Management Journal, 42, 58-74.

Lam, C. K., Huang, X., \& Chan, S. C. (2015). The Threshold Effect of Participative Leadership and the Role of Leader Information Sharing. Academy of Management Journal, 58, 836-855. https://doi.org/10.5465/amj.2013.0427

Lawler, E. E., Mohrman, S. A., \& Benson, G. (2001). Organizing for High Performance: Employee Involvement, TQM, Reengineering, and Knowledge Management in the Fortune 1000. San Francisco, CA: Jossey-Bass. 
Li, Y., \& Wei, F. (2010). Evolution of Leadership Theory and Frontier Progress. Journal of Management, 4, 517-524.

Liden, R. C., Erdogan, B., Wayne, S. J., \& Sparrowe, R. T. (2006). Leader-Member Exchange, Differentiation, and Task Interdependence: Implications for Individual and Group Performance. Journal of Organizational Behavior, 27, 723-746. https://doi.org/10.1002/job.409

Locke, E. A., \& Schweiger, D. M. (1979). Participation in Decision-Making: One More Look. In B. M. Staw (Ed.), Research in Organizational Behavior (pp. 265-339). Greenwich, CT: JAI Press.

Lorinkova, N. M., \& Perry, S. J. (2017). When Is Empowerment Effective? The Role of Leader-Leader Exchange in Empowering Leadership, Cynicism, and Time Theft. Journal of Management, 43, 1631-1654. https://doi.org/10.1177\%2F0149206314560411

Lorinkova, N., Pearsall, M., \& Sims, H. (2013). Examining the Differential Longitudinal Performance of Directive versus Empowering Leadership in Teams. Academy of Management Journal, 56, 573-596. https://doi.org/10.5465/amj.2011.0132

Magee, J. C., et al. (2008). Power and the Objectification of Social Targets. Journal of Personality \& Social Psychology, 95, 111-127.

Manz, C. C., \& Sims Jr., H. P. (1980). Self-Management as a Substitute for Leadership: A Social Learning Theory Perspective. Academy of Management Review, 5, 361-367. https://doi.org/10.5465/amr.1980.4288845

Manz, C. C., \& Sims Jr., H. P. (1987). Leading Workers to Lead Themselves: The External Leadership of Self-Managing Work Teams. Administrative Science Quarterly, 32, 106129. https://doi.org/10.2307/2392745

Manz, C. C., \& Sims Jr., H. P. (2001). The New Super Leadership: Leading Others to Lead Themselves. Oakland, CA: Berrett-Koehler Publishers.

Manz, C.C., \& Sims Jr., H.P. (1990) Super Leadership. New York, NY: Berkeley Books.

Markham, S. E., \& Markham, I. S. (1995). Self-Management and Self-Leadership Reexamined: A Levels-of-Analysis Perspective. The Leadership Quarterly, 6, 343-359. https://doi.org/10.1016/1048-9843(95)90013-6

Mathieu, J. E., Hollenbeck, J. R., van Knippenberg, D., \& Ilgen, D. R. (2017). A Century of Work Teams in the Journal of Applied Psychology. Journal of Applied Psychology, 102, 452-467. https://doi.org/10.1037/apl0000128

Maynard, M. T., Gilson, L. L., \& Mathieu, J. E. (2012). Empowerment-Fad or Fab? A Multilevel Review of the Past Two Decades of Research. Journal of Management, 38, 1231-1281. https://doi.org/10.1177\%2F0149206312438773

McClelland, D. C. (1975). Power: The Inner Experience (Vol. 95, pp. 427-429). New York, NY: Irvington Publishers.

Menon, S. (2001). Employee Empowerment: An Integrative Psychological Approach. Applied Psychology, 50, 153-180.

Meuser, J. D., Gardner, W. L., Dinh, J. E., Hu, J., Liden, R. C., \& Lord, R. G. (2016). A Network Analysis of Leadership Theory: The Infancy of Integration. Journal of Management, 42, 1374-1403. https://doi.org/10.1177\%2F0149206316647099

Palanski, M. E., \& Yammarino, F. J. (2009). Integrity and Leadership: A Multi-Level Conceptual Framework. The Leadership Quarterly, 20, 405-420. https://doi.org/10.1016/j.leaqua.2009.03.008

Pearce, C. L., \& Sims Jr., H. P. (2002). Vertical versus Shared Leadership as Predictors of the Effectiveness of Change Management Teams: An Examination of Aversive, Directive, Transactional, Transformational, and Empowering Leader Behaviors. Group Dy- 
namics: Theory, Research, and Practice, 6, 172-197.

https://doi.org/10.1037/1089-2699.6.2.172

Pearce, C.L., Sims, H.P., Cox, J.F., Ball, G., Schnell, E., Smith, K.A., \& Trevino, L. (2003). Transactors, Transformers and Beyond: A Multi-Method Development of a Theoretical Typology of Leadership. Journal of Management Development, 22, 273-307. https://doi.org/10.1108/02621710310467587

Raub, S., \& Robert, C. (2010). Differential Effects of Empowering Leadership on In-Role and Extra-Role Employee Behaviors: Exploring the Role of Psychological Empowerment and Power Values. Human Relations, 63, 1743-1770. https://doi.org/10.1177\%2F0018726710365092

Seibert, S. E., Wang, G., \& Courtright, S. H. (2011). Antecedents and Consequences of Psychological and Team Empowerment in Organizations: A Meta-Analytic Review. Journal of Applied Psychology, 96, 981-1003. https://doi.org/10.1037/a0022676

Sharma, P. N., \& Kirkman, B. L. (2015). Leveraging Leaders: A Literature Review and Future Lines of Inquiry for Empowering Leadership Research. Group \& Organization Management, 40, 193-237. https://doi.org/10.1177\%2F1059601115574906

Sims Jr., H. P., Faraj, S., \& Yun, S. (2009). When Should a Leader Be Directive or Empowering? How to Develop Your Own Situational Theory of Leadership. Business Horizons, 52, 149-158. https://doi.org/10.1016/j.bushor.2008.10.002

Spreitzer, G. M. (1995). Psychological Empowerment in the Work-Place: Dimensions, Measurement, and Validation. Academy of Management Journal, 38, 1442-1465. https://doi.org/10.5465/256865

Spreitzer, G. M., Kizilos, M. A., \& Nason, S. W. (1997). A Dimensional Analysis of the Relationship between Psychological Empowerment and Effectiveness Satisfaction, and Strain. Journal of Management, 23, 679-704. https://doi.org/10.1177\%2F014920639702300504

Strauss, G. (1964). Some Notes on Power Equalization. In H. J. Leavitt (Ed.), The Social Science of Organizations: Four Perspectives. Englewood Cliffs, NJ: Prentice-Hall.

Tekleab, A. G., Sims Jr., H. P., Yun, S., Tesluk, P. E., \& Cox, J. (2008). Are We on the Same Page? Effects on Self-Awareness of Empowering and Transformational Leadership. Journal of Leadership and Organizational Studies, 14, 185-201. https://doi.org/10.1177\%2F1071791907311069

Thomas, K. W., \& Velthouse, B. A. (1990). Cognitive Elements of Empowerment: An "Interpretive" Model of Intrinsic Task Motivation. Academy of Management Review, 15, 666-681. https://doi.org/10.5465/amr.1990.4310926

Tuckey, M. R., Bakker, A. B., \& Dollard, M. F. (2012). Empowering Leaders Optimize Working Conditions for Engagement: A Multilevel Study. Journal of Occupational Health Psychology, 17, 15-27. https://doi.org/10.5465/amr.1990.4310926

Vroom, V. H., \& Jago, A. G. (2007). The Role of the Situation in Leadership. American Psychologist, 62, 17-24. https://doi.org/10.1037/0003-066X.62.1.17

Vroom, V. H., \& Yetton, P. W. (1973). Leadership and Decision Making. Pittsburgh, PA: University of Pittsburgh Press. https://doi.org/10.2307/j.ctt6wrc8r

Wellins, R. S., Byham, W. and Wilson, J. (1991). Empowered Teams: Creating Self-Directed Work Groups That Improve Quality, Productivity, and Participation. San Francisco, CA: Jossey-Bass.

Yammarino, F. J. (2012). Leadership. In V. S. Ramachandran (Ed.), Encyclopedia of Human Behavior (2nd ed., pp. 517-524). Oxford: Academic Press.

https://doi.org/10.1016/B978-0-12-375000-6.00219-6 
Yammarino, F. J., \& Bass, B. M. (1990). Transformational Leadership and Multiple Levels of Analysis. Human Relations, 43, 975-995. https://doi.org/10.1177\%2F001872679004301003

Yukl, G. (2002). Leadership in Organizations. Upper-Saddle River, NJ: Pearson Education.

Yun, S., Cox, J., \& Sims Jr., H. P. (2006). The Forgotten Follower: A Contingency Model of Leadership and Follower Self-Leadership. Journal of Managerial Psychology, 21, 374388. https://doi.org/10.1108/02683940610663141

Zhang, X. M. \& Bartol, K. M. (2010). Linking Empowering Leadership and Employee Creativity: The Influence of Psychological Empowerment, Intrinsic Motivation, and Creative Process Engagement. Academy of Management Journal, 53, 107-128.

https://doi.org/10.5465/amj.2010.48037118 